\title{
Availability of Analgesic and Anti-Inflammatory Medicines in Primary Health Care
}

\author{
Jacqueline Silva Santos ${ }^{1}\left(0\right.$, Alex Junio Silva da Cruz ${ }^{\circledR}$, Lia Silva de Castilho®, Mauro Henrique \\ Nogueira Guimarães Abreu'1(i)
}

\begin{abstract}
${ }^{1}$ Department of Community and Preventive Dentistry, School of Dentistry, Federal University of Minas Gerais, Belo Horizonte, MG, Brazil.

2Department of Restorative Dentistry, School of Dentistry, Federal University of Minas Gerais, Belo Horizonte, MG, Brazil.
\end{abstract}

Author to whom correspondence should be addressed: Lia Silva de Castilho, Departamento de Odontologia Restauradora, Faculdade de Odontologia, Universidade Federal de Minas Gerais, R. Prof. Moacir Gomes de Freitas, 688 - Pampulha, Belo Horizonte, MG, Brazil. 31270-901. Phone: + 5531 34092470. E-mail: liasc@ufmg.br.

Academic Editors: Alessandro Leite Cavalcanti and Wilton Wilney Nascimento Padilha

Received: 19 September 2019 / Accepted: 02 March 2020 / Published: 09 March 2020

How to cite this article: Santos JS, Cruz AJS, Castilho LS, Abreu MHNG. Availability of analgesic and anti-inflammatory medicines in primary health care. Pesqui Bras Odontopediatria Clín Integr. 2020; $20:$ e5236. https://doi.org/10.1590/pboci.2020.045

\begin{abstract}
Objective: To describe and analyze the availability and factors related to the presence of analgesics and non-steroidal anti-inflammatory drugs in the Brazilian public primary healthcare system. Material and Methods: This was a cross-sectional study that evaluated 17,903 health units that participated in the National Program for Primary Care Access and Quality Improvement (2013-2014). The dependent variable was defined as the presence of metamizole, ibuprofen, and acetaminophen in a sufficient amount. The independent variables included the type of primary health care unit, the presence of a medication disposal area, the number of physicians, nurses, and dental practitioners; and the number of primary care units with family and oral health teams. For statistical analysis, unadjusted and adjusted Odds Ratio (OR) (95\% CI) were presented. Results: The three medicines were available in $62.4 \%$ of the units. Regarding Health Clinics, the Basic Health Units (OR= 1.31, CI95\% 1.18-1.44), Polyclinic (OR=2.00, 95\% CI, 1.15 -3.48), and others $(\mathrm{OR}=1.37 ; 95 \% \mathrm{CI} 1.14-1.63)$ had higher chances of availability of all three drugs. The presence of a disposal area $(\mathrm{OR}=1.64,95 \% \mathrm{CI} 1.51-1.77)$ and the number of physicians $(\mathrm{OR}=1.04,95 \% \mathrm{CI} 1.00-1.08)$, nurses $(\mathrm{OR}=1.08,95 \% \mathrm{CI} 1.03-1.13)$, and dental practitioners $(\mathrm{OR}=1.09,95 \%$ CI 1.04-1.14) increased the availability odds of the analyzed drugs in the service. Conclusion: The structure of the healthcare units and the higher number of professionals were positively associated with the availability of these drugs.

Keywords: Primary Health Care; Pharmaceutical Services; Drugs, Essential.
\end{abstract}




\section{Introduction}

Pain is a highly prevalent condition worldwide [1], as well as a major clinical, social, and economic issue that negatively impacts people's quality of life [1-3]. In Brazil, it was estimated that $39 \%$ of adults suffer from chronic pain. Of these, $75 \%$ use painkillers, with analgesic and non-steroidal anti-inflammatory drugs (NSAIDs) being the most commonly consumed [4]. These drugs are a heterogeneous group of chemicals that share therapeutic activities, such as anti-inflammatory, analgesic, and antipyretic properties [5]. Regarding this matter, analgesics are among the most prescribed medicines and are considered to be "essential medicines" by the World Health Organization (WHO) [6-8].

Analgesics are the most consumed drugs in Brazil [9,10] and Primary Health Care (PHC) from the Brazilian National Health System (Sistema Único de Saúde - SUS, in Portuguese) should give comprehensive therapeutic care, including pharmaceutical [11]. The Brazilian Medicine Policy (PNM) [12] and the Brazilian Pharmaceutical Services Policy (PSP) [13] focus on access to safe, efficient, and high-quality medicines in the PHC. These policies have also adopted the National List of Essential Medicines (Relação Nacional de Medicamentos Essenciais - RENAME, in Portuguese), based on the WHO model list of essential medicines [8].

PHC has been evaluated in order to improve the quality and access of services to the population. The National Program for Primary Care Access and Quality Improvement (Programa Nacional de Melhoria do Acesso e da Qualidade da Atenção Básica - PMAQ-AB, in Portuguese) was a national strategy used by the Federal Government for this purpose. In the last decade, three cycles of national PHC evaluation have been developed by PMAQ-AB and the obtained data has been published. These surveys considered the characteristics of the healthcare services, including access to such essential medications as vitamins, antihypertensives, antidiabetics, analgesics and antipyretics, NSAIDS, antimicrobials, and psychotropics [14-16].

The lack of continuous access to essential medicines is a major public health issue, not only in Brazil but throughout the world. The WHO estimates that one-third of the world's population does not have regular access to these medicines [17]. Physical structure, the good management of the healthcare services, and the presence of the pharmacist in the PHC units seems to be associated with higher availability rates [18-20].

PHC should provide essential medicines to the entire Brazilian population; however, out-of-pocket expenditure has been increasing over the years, compromising families' incomes [21]. Considering Brazil's huge territorial extension and the striking socioeconomic inequalities, few nationwide initiatives actually evaluate drug availability. In this light, this study aimed to describe and analyze the availability and factors related to the presence of analgesics and NSAIDS in the Brazilian public primary healthcare system.

\section{Material and Methods}

Study Design

This is an analytical cross-sectional study that analyzed secondary data from 24,055 PHC units' participants from the PMAQ-AB second cycle in Brazil (2013-2014). This is an open dataset that is available from the Brazilian Ministry of Health (MH) [22].

The PMAQ-AB was introduced by the MH in 2011. The program's main goals were to improve access and the quality of healthcare services in PHC. It consisted of the mobilization of employees, managers, and users, aiming to bring about change in the work process and in the guidelines of PHC services according to the needs and satisfaction of the population. PMAQ-AB was an articulated strategy that consisted of the assessment and certification of PHC teams. Moreover, in accordance with the performance achieved by these 
teams in the implementation and development of the standards and indicators evaluated by the program, financial incentives were transferred to the counties where the teams worked $[14,15]$.

\section{Data Collection}

Data on the characteristics of the PHC units were collected by a questionnaire that included, among other items, the presence of medicines. Both the development of the questionnaire used in the interviews and the data collection from health professionals were carried out with the collaboration of 46 Brazilian education and research institutions. The 989 interviewers were all senior healthcare professionals and were trained to conduct this survey nationwide. A 40-hour training included PHC content, survey methods, and PMAQ-AB questionnaires. All interviewers participated in a formal evaluation to assess their abilities. One supervisor was assigned to every three interviewers. The Brazilian MH developed an app for mobile devices, which presented the questions in an electronic format, thus allowing for data collection. Data were directly sent to an online database, and the MH was subsequently responsible for the analysis of consistency and the certification of the healthcare teams [15].

The interviewed population consisted of Brazilian health professionals who worked in PHC units that participated in the second cycle of PMAQ-AB. The interview with health professionals was voluntary. A total of 6,152 PHC units that did not dispose of medicines were excluded from this study. Therefore, this research considered 17,903 PHC units, where the drug disposal process was performed.

The dependent variable in this study was defined as the presence of metamizole, ibuprofen, and acetaminophen in a sufficient amount, according to the perception of the interviewee, at PHC units. The dependent variable was evaluated qualitatively, that is, the interviewee's answer has been taken for granted. The MH claims that it would be impossible to define only one quantitative criterion to asses all the medicines and supplies.

The independent variables included the type of PHC unit (health clinic, basic health unit, polyclinic, others); PHC units with a medication disposal area (yes/no); the number of physicians, nurses, and dental practitioners; and the number of PHC units with family and oral health teams.

\section{Data Analysis}

For statistical analysis, the SPSS Program, version 17.0, was used. Descriptive statistics and multivariate statistics were performed through binary logistical regression. First, each independent variable was tested one by one. Those with a p-value of less than 0.25 were included in the final model. Non-adjusted and adjusted Odds Ratio (95\% Confidence Interval - 95\% CI) were also estimated, using a Forward Stepwise method. Only variables with a p-value of less than 0.05 were maintained in the final model. The linearity of the logit was checked for continuous variables. Residuals were evaluated by Cook's distance and multicollinearity were evaluated by the Variance Inflation Factor (VIF). Hosmer \& Lemeshow's goodness of fit test was also performed.

Ethical Aspects

The Research Ethics Committee of the Federal University of Minas Gerais approved this research, logged under Protocol No. O23965 12.8.0000.5149.

\section{Results}


The overall availability in the PHC units of the three medicines in sufficient amounts was $62.4 \%$. The variable descriptions are presented in Table 1.

Table 1. Description of the analyzed variables on the external evaluation from the second's PMAQ-AB cycle.

\begin{tabular}{|c|c|c|}
\hline Variables & $\mathbf{N}$ & $\%$ \\
\hline \multicolumn{3}{|l|}{ Type of PHC Unit } \\
\hline Health Clinic & 1,756 & 9.8 \\
\hline Basic Health Unit & 15,334 & 85.6 \\
\hline Policlinic & 68 & 0.4 \\
\hline Other & 745 & 4.2 \\
\hline \multicolumn{3}{|l|}{ PHC units with a Medication Disposal Area } \\
\hline Yes & 14,950 & 83.5 \\
\hline No & 2,953 & 16.5 \\
\hline \multicolumn{3}{|l|}{ Metamizole in Sufficient Amount } \\
\hline Yes & 14,392 & 80.4 \\
\hline No & 3,511 & 19.6 \\
\hline \multicolumn{3}{|l|}{ Ibuprofen in Sufficient Amount } \\
\hline Yes & 13,397 & 74.8 \\
\hline No & 4,506 & 2.2 \\
\hline \multicolumn{3}{|l|}{ Acetaminophen in Sufficient Amount } \\
\hline Yes & 15,574 & 87.0 \\
\hline No & 2,329 & 13.0 \\
\hline \multicolumn{3}{|l|}{ Metamizole, Ibuprofen and Acetaminophen in Sufficient Amount } \\
\hline Yes & 11,171 & 62.4 \\
\hline No & 6,732 & 37.6 \\
\hline Number of Healthcare Professionals & Median & Range \\
\hline Physicians & 1 & $0-21$ \\
\hline Nurses & 1 & $0-18$ \\
\hline Dental Practitioners & 1 & $0-19$ \\
\hline Number of PHC Units with Family and Oral Health Teams & 1 & $0-15$ \\
\hline
\end{tabular}

The final model identified that, when compared to health clinics (Posto de Saúde, in Portuguese), basic health units $(\mathrm{OR}=1.31$, CI95\% 1.18-1.44), polyclinics $(\mathrm{OR}=2.00,95 \% \mathrm{CI}, 1.15-3.48)$, and other PHC units $(\mathrm{OR}=1.37 ; 95 \%$ CI 1.14-1.63) showed an increased chance of presenting the three drugs. PHC units with a medication disposal area $(\mathrm{OR}=1.64,95 \% \mathrm{CI} 1.51-1.77)$ and the number of physicians $(\mathrm{OR}=1.04,95 \% \mathrm{CI}$ 1.00-1.08), nurses $(\mathrm{OR}=1.08,95 \% \mathrm{CI} 1.03-1.13)$, and dental practitioners $(\mathrm{OR}=1.09,95 \%$ CI 1.04-1.14) increased the odds for availability of the drugs in the healthcare service (Table 2 ).

Table 2. Associated factors related to the presence of analgesics and NSAIDs in a sufficient amount.

\begin{tabular}{|c|c|c|c|c|}
\hline Variables & Unadjusted OR & & Adjusted OR & \\
\hline & (CI95\%) & p-value & (CI95\%) & p-value \\
\hline Type of PHC Unit & & & & \\
\hline Health Clinic & 1 & - & 1 & - \\
\hline Basic Health Unit & $1.37(1.24-1.51)$ & $<0.001$ & $1.31(1.18-1.44)$ & $<0.001$ \\
\hline Policlinic & $2.23(1.29-3.85)$ & 0.004 & $2.00(1.15-3.48)$ & 0.014 \\
\hline Other & $1.46(1.22-1.74)$ & $<0.001$ & $1.37(1.14-1.63)$ & $<0.001$ \\
\hline
\end{tabular}

PHC Units with a Medication Disposal Area
No
Yes
$1.76(1.62-1.90)$
$<0.001$
1
$1.64(1.51-1.77)$
$<0.001$ 


\begin{tabular}{llllc}
$\begin{array}{l}\text { Number of Healthcare Professionals } \\
\text { Physicians }\end{array}$ & $1.14(1.12-1.17)$ & $<0.001$ & $1.04(1.00-1.08)$ & 0.032 \\
$\quad$ Nurses & $1.19(1.16-1.23)$ & $<0.001$ & $1.08(1.03-1.13)$ & 0.003 \\
$\quad \begin{array}{l}\text { Dental Practitioners } \\
\text { Number of PHC Units with Family }\end{array}$ & $1.21(1.17-1.27)$ & $<0.001$ & $1.09(1.04-1.14)$ & $<0.001$ \\
and Oral Health Teams & & & - & - \\
\hline PHC: Primary Health Care.
\end{tabular}

None of the continuous variables violated the assumption of the linearity of logit. Cook's Distance was lower than 1 (ranging from 0.0001 to 0.1174 ), indicating no influential cases. VIF values ranged from 1.019 to 2.669, indicating no issue in multicollinearity. The multiple logistical regression model was considered adequate ( $\mathrm{p}=0.573$; Hosmer-Lemeshow's test).

\section{Discussion}

In this study, the number of PHC units where the analyzed medicines were available in sufficient amounts was $62.4 \%$. The type of PHC unit, the presence of a medication disposal area, and the number of physicians, nurses, and dental practitioners were positively associated with the outcome.

The adequate physical structure of the PHC units was directly associated with the higher availability of painkillers. Some published studies indicate that more well-structured healthcare units have better conditions to stock the medicines properly. Moreover, temperature control by an air-conditioning system in the storage room, the presence of a refrigerator in which to lay thermolabile medications, and the presence of a computerized system were linked to higher availability rates [18-20]. According to current Brazilian legislation, a health clinic is a unit that provides health assistance to a specific population by a mid-level professional, with or without the intermittent physical presence of a physician [23]. This might explain the lowest availability of metamizole, acetaminophen, and ibuprofen found in the health clinics, since the physician might not always be in the unit and mid-level professionals, according to Brazilian legislation, are not allowed to prescribe medications. Regarding the polyclinics, these PHC units offer outpatient care in many specialties, including non-medical care [23]; hence, the higher density of healthcare professionals is believed to be found in these units. Therefore, the polyclinics might be a planned facility to support the demand and host the necessary equipment. This corroborates the findings in this survey that physical structure and human resources are associated with higher odds of the PHC unit having the three analyzed medicines.

Healthcare professionals who are able to prescribe medications include physicians, nurses, and dental practitioners. It was estimated that more than $60 \%$ of all doctor's or dentist's appointments result in prescriptions [24]. As analgesics and NSAIDs are widely prescribed and consumed in Brazil [9,10], it is expected that the PHC units that have a higher number of healthcare professionals will consequently have higher availability rates.

The main goals of the PNM and the PSP are to guide the acquisition of medicine and their distribution, ensuring the rational use of drugs and promoting the population's access to essential medicine $[12,13]$. Despite these policies, this study noticed that $37.6 \%$ of the PHC facilities did not have the analyzed medicines in sufficient amounts, even though metamizole, ibuprofen, and acetaminophen are part of the RENAME and are being manufactured by Brazil's Official Pharmaceutical Laboratories [25].

Metamizole, acetaminophen, and ibuprofen occupied the $7 \mathrm{th}, 8 \mathrm{th}$, and 12 th positions, respectively, in a ranking of the medicines most used by outpatients in PHC in the public sector [10]. This could be explained by the broad spectrum of conditions treated by these medicines, including rheumatoid arthritis, osteoarthritis, 
musculoskeletal pain, pre-emptive and post-operative surgeries, dental treatments, among others [26-28]. Insufficient access to these medicines means that a large percentage of the Brazilian population experience the burdens of acute and chronic pain, such as delayed wound healing, increased number of secondary doctor's appointments, and additional treatment costs. Pain is known to be a noxious experience and can have a negative effect on almost every other aspect of life, including one's daily routine, mood, and decline in work productivity [6].

Previous research evaluated adults' access to medicines to manage acute medical conditions in the Brazilian Northeast and South. It was found that in both geographic regions the greater access to analgesic and NSAIDs prescribed in the SUS was paid out-of-pocket [21]. According to the WHO, drug-related expenses is the largest family expenditure item after food supply [29]. This highlights the economic burden of the lack of access to essential medicines, especially between people in disadvantaged or low-income regions.

In Brazil, the pharmaceutical assistance of the entire public health system is decentralized. Poor planning, lackluster management, and the lack of financial resources from funding sources are associated with low medicine availability rates [19]. Previous research proposes interventions to cope with this low availability, such as social control, the existence of a Permanent Bidding Committee to buy medicines, and the regular participation of the professionals responsible for the disposal of medicines in the Municipal health council meetings [20].

The disposal of basic components of the medicines in primary care are the responsibility of the municipal government. RENAME is a referential instrument to guide the selection of drugs, but the Brazilian counties' managers have the autonomy to create a list of essential medicines according to the population's epidemiological demand [12]. The limitations of this study were that the low availability of the medicines analyzed could have been compensated by the offer of other products with the same indication defined by the municipal level. The huge number of counties in Brazil also made it impossible to verify those lists, which is a limitation also reported in prior studies [18]. Another limitation is that the assessment process of availability occurred within a single measurement, which does not reflect the dynamic reality of the input and output within the medicine disposal process. This directs attention to the need for further research in the availability of medicines in Brazil.

\section{Conclusion}

Regarding the PHC units analyzed in this survey, more than a third did not have metamizole, ibuprofen, and acetaminophen in sufficient amounts. The physical structure, an area for medicine disposal, and the number of health professionals were directly associated with a higher probability of the availability of these drugs.

\section{Authors' Contributions}

\begin{tabular}{|c|c|c|}
\hline JSS & (iD) $0000-0003-0572-4668$ & $\begin{array}{l}\text { Conceptualization, Investigation, Formal Analysis and Writing - Original Draft } \\
\text { Preparation. }\end{array}$ \\
\hline AJSC & (iD) $0000-0003-1905-4124$ & Formal Analysis and Writing - Original Draft Preparation. \\
\hline LSC & (iD) $0000-0001-9648-6815$ & Formal Analysis and Writing - Original Draft Preparation. \\
\hline MHNA & (iD) $0000-0001-8794-5725$ & $\begin{array}{l}\text { Conceptualization, Methodology, Formal Analysis and Writing - Review and } \\
\text { Editing. }\end{array}$ \\
\hline
\end{tabular}




\section{Financial Support}

Supporting Research Foundation of the state of Minas Gerais - FAPEMIG (\#001), National Council for Scientific and Technological Development - CNPq (303772/2019-0) and the Coordenação de Aperfeiçoamento de Pessoal de Nível Superior - Brasil (CAPES) - Finance Code 001.

\section{Conflict of Interest}

The authors declare no conflicts of interest.

\section{References}

[1] Collaborators Global Burden of Disease (GBD). Global, regional, and national incidence, prevalence, and years lived with disability for 301 acute and chronic diseases and injuries in 188 countries, 1990-2013: a systematic analysis for the Global Burden of Disease Study 2013. Lancet 2015; 386(9995):743-800.

https://doi.org/10.1016/So140-6736(15)60692-4

[2] Strand EB, Mengshoel AM, Sandvik L, Helland IB, Abraham S, Nes LS. Pain is associated with reduced quality of life and functional status in patients with myalgic encephalomyelitis/chronic fatigue syndrome. Scand J Pain 2019; 19(1):61-72. https://doi.org/10.1515/sjpain-2018-0095

[3] Husky MM, Ferdous Farin F, Compagnone P, Fermanian C, Kovess-Masfety V. Chronic back pain and its association with quality of life in a large French population survey. Health Qual Life Outcomes 2018; 16(1):195. https://doi.org/10.1186/s12955-018-1018-4

[4] de Souza JB, Grossmann E, Perissinotti DMN, de Oliveira Junior JO, da Fonseca PRB, Posso IP. Prevalence of chronic pain, treatments, perception, and interference on life activities: Brazilian population-based survey. Pain Res Manag 2017; 2017:4643830. https://doi.org/10.1155/2017/4643830

[5] Vuilleumier PH, Schliessbach J, Curatolo M. Current evidence for central analgesic effects of NSAIDs: an overview of the literature. Minerva Anestesiol 2018; 84(7):865-70. https://doi.org/10.23736/So375-9393.18.12607-1

[6] Brune K, Patrignani P. New insights into the use of currently available non-steroidal anti-inflammatory drugs. J Pain Res 2015; 8:105-18. https://doi.org/10.2147/JPR.S75160

[7] Al-Shidhani A, Al-Rawahi N, Al-Rawahi A, P SM. Non-steroidal anti-inflammatory drugs (NSAIDs) use in primary health care centers in A'Seeb, Muscat: a clinical audit. Oman Med J 2015; 30(5):366-71. https://doi.org/10.5001/omj.2015.73

[8] World Health Organization. 21st WHO Model List of Essential Medicines. Available from: https://apps.who.int/iris/bitstream/handle/10665/325771/WHO-MVP-EMP-IAU-2019.06-eng.pdf?ua=1. [Accessed on February 23, 2020].

[9] da Silva Dal Pizzol T, Turmina Fontanella A, Cardoso Ferreira MB, Dâmaso Bertoldi A, Boff Borges R, Serrate Mengue S. Analgesic use among the Brazilian population: results from the national survey on access, use and promotion of rational use of medicines (PNAUM). PLoS One 2019; 14(3):e0214329. https://doi.org/10.1371/journal.pone.0214329

[10] Costa CMFN, Silveira MR, Acurcio FA, Guerra AA, Guibu IA, Costa KS, et al. Use of medicines by patients of the primary health care of the Brazilian Unified Health System. Rev Saúde Pública 2017; 51(suppl 2):18s. https://doi.org/10.11606/S1518-8787.2017051007144

[11] Brasil. Lei no 8.080 , de 19 de setembro de 1990. Dispõe sobre as condições para a promoção, proteção e recuperação da saúde, a organização e o funcionamento dos serviços correspondentes e dá outras providências. Brasília: Diário Oficial da União. Section 1:018055. [In Portuguese].

[12] Brasil. Ministério da Saúde. Portaria n ${ }^{\circ}$ 3.916, de 30 de outubro de 1998. Aprova a Política Nacional de Medicamentos e dá outras providências. Brasília: Diário Oficial União; 1998 Oct. 30. Section 1:18. Available from: http://bvsms.saude.gov.br/bvs/saudelegis/gm/1998/prt3916_30_10_1998.html. [Accessed on February 23, 2020].

[In Portuguese].

[13] Brasil. Ministério da Saúde. Conselho Nacional de Saúde. Resolução n. 338, de 06 de maio de 2004. Aprova a Política Nacional de Assistência Farmacêutica [Internet]. Brasília: Diário Oficial União; 2004 May 06. Section 1:52. Available from: http://bvsms.saude.gov.br/bvs/saudelegis/cns/2004/res0338_06_05_2004.html. [Accessed on February 23, 2020]. [In Portuguese].

[14] Brasil. Ministério da Saúde. Programa Nacional de Melhoria do Acesso e da Qualidade da Atenção Básica (PMAQAB): Manual Instrutivo [Internet]. Brasília: Ministério da Saúde; 2015. Available from: http://bvsms.saude.gov.br/bvs/publicacoes/manual_instrutivo_pmaq_atencao_basica.pdf. [Accessed on February 23, 2020]. [In Portuguese].

[15] Brasil. Programa Nacional de Melhoria do Acesso e da Qualidade da Atenção Básica (PMAQ). Brasília: Ministério da Saúde Available from: http://aps.saude.gov.br/ape/pmaq. [Accessed on February 23, 2020]. [In Portuguese]. 
[16] Souza MF, Santos AFD, Reis IA, Santos MADC, Jorge AO, Machado ATGD, et al. Care coordination in PMAQ-AB: An Item Response Theory-based analysis. Rev Saúde Pública 2017; 51:87. https://doi.org/10.11606/S1518-8787.2017051007024

[17] World Health Organization. Equitable access to essential medicines: a framework for collective action. Available from: http://apps.who.int/iris/bitstream/handle/10665/68571/WHO_EDM_2004.4_eng.pdf?sequence=1\&is Allowed=y. [Accessed on February 23, 2020]. [In Portuguese].

[18] Mendes LV, Campos MR, Chaves GC, Silva RMd, Freitas PdS, Costa KS, et al. Availability of medicines in primary health care facilities and related factors: a cross sectional approach. Saúde Debate 2014; 38(spe):109-23. https://doi.org/10.5935/0103-1104.2014So09

[19] Nascimento RCRM, Álvares J, Guerra AA, Gomes IC, Costa EA, Leite SN, et al. Availability of essential medicines in primary health care of the Brazilian Unified Health System. Rev Saúde Pública. 2017; 51(suppl 2):10s. https://doi.org/10.11606/s1518-8787.2017051007062

[20] Barros RD, Costa EA, Santos DBD, Souza GS, Álvares J, Guerra AA, et al. Access to medicines: relations with the institutionalization of pharmaceutical services. Rev Saúde Pública. 2017; $51($ suppl 2$): 8 s$. https://doi.org/10.11606/S1518-8787.2017051007138

[21] Paniz VMV, Cechin ICCF, Fassa AG, Piccini RX, Tomasi E, Thumé E, et al. Access to medicines prescribed for acute health conditions in adults in South and Northeast Brazil. Cad Saúde Pública 2016; 32(4):e00009915-e. https://doi.org/10.1590/0102-311X00009915

[22] Brasil. Ministério da Saúde. Brasília: Programa de Melhoria do Acesso e da Qualidade - 2 ciclo. Available from: http://aps.saude.gov.br/ape/pmaq/ciclo2/. [Accessed on August 20, 2019]. [In Portuguese].

[23] Brasil. Ministério da Saúde. Secretaria de Assistência à Saúde. Portaria no 511 de 29 de dezembro de 2000. Aprova a Ficha Cadastral dos Estabelecimentos de Saúde - FCES, o Manual de Preenchimento e a planilha de dados profissionais constantes no Anexo I, Anexo II, Anexo III, desta Portaria, bem como a criação do Banco de Dados Nacional de Estabelecimentos de Saúde. Brasília: Ministério da Saúde; 2001. Available from: https://www.cremers.org.br/pdf/pj/PORT_SAS_511_2000.pdf. [Accessed on February 24, 2020]. [In Portuguese].

[24] Boing AC, Bertoldi AD, Boing AF, Bastos JL, Peres KG. Access to medicines in the public sector: analysis of users of the Brazilian Unified National Health System. Cad Saúde Pública 2013; 29(4):691-701. https://doi.org/10.1590/So102-311X2013000400007

[25] Yamauti SM, Barberato-Filho S, Lopes LC. The list of drugs in the Popular Pharmacy Program and the Brazilian National Pharmaceutical Care Policy. Cad Saúde Pública 2015; 31:1648-62. https://doi.org/10.1590/0102-311X00054814

[26] Sparks JA. Rheumatoid arthritis. Ann Intern Med 2019; 170(1):ITC1-ITC16. https://doi.org/10.7326/AITC201901010

[27] Enthoven WTM, Roelofs PD, Koes BW. NSAIDs for chronic low back pain. JAMA 2017; 317(22):2327-8. https://doi.org/10.1001/jama.2017.4571

[28] Pereira GM, Cota LO, Lima RP, Costa FO. Effect of preemptive analgesia with ibuprofen in the control of postoperative pain in dental implant surgeries: a randomized, triple-blind controlled clinical trial. J Clin Exp Dent 2020; 12(1): e71-e8. https://doi.org/10.4317/jced.56171

[29] World Health Organization. Addressing the global shortage of, and access to, medicines and vaccines. Available from: http://apps.who.int/gb/ebwha/pdf_files/EB142/B142_13-en.pdf. [Accessed on February 23, 2020]. [In Portuguese]. 